\title{
PENERAPAN BAHAN AJAR TERINTEGRASI NILAI KARAKTER DALAM MODEL PEMBELAJARAN ADVANCE ORGANIZER PADA SISWA KELAS X SMA NEGERI 2 PADANG
}

\author{
Aldila Rahayu' ${ }^{1}$ Masril $^{2}$, Hidayati \\ ${ }^{1}$ Mahasiswa Pendidikan Fisika FMIPA Universitas Negeri Padang \\ Email: aldilarahayu27@yahoo.co.id \\ ${ }^{2}$ Staf Pengajar Jurusan Fisika FMIPA Universitas Negeri Padang
}

\begin{abstract}
The teachers have to be able to develop their own learning instrumental, one is instructional material. Based on the demand of character education, the instructional material is needed to help the teachers to cultivate the character value to students. This research aims to know the effects of Implicating Intregated Material of Character Value in the Teaching Model Advance Organizer to the First Year Students of SMA Negeri 2 Padang. The type of the research is quasi-experimental. Population of the research is all students grade X of SMA Negeri 2 Padang year 2013/2014. Sample is taken by using clauster random sampling technique. The technique of data collection for cognitive domain is written test, while for affective and psychomotor domain is by doing obeservation. The technique of data analysis is by using $t$ formula for cognitive and psychomotor domain, mean while for affective domain is descriptive data with graphics. Research findings acquire: 1 ) for cognitive domain $t_{\text {count }}=2,17$ while $t_{\text {table }}=1,67$ (in the area of refusal $\mathrm{H}_{0}$ until $\mathrm{H}_{\mathrm{i}}$ accepted). 2) for psychomotor domain $\mathrm{t}_{\text {count }}=6,42$ while $\mathrm{t}_{\text {table }}=1,67$ (in the area of refusal $\mathrm{H}_{0}$ until $\mathrm{H}_{\mathrm{i}}$ accepted). For affective domain, the character value is 80 in average. The conclusion is based on the hypothesis that "there are meaningful effects of Implicating Intregated Material of Character Value in the Teaching Model Advance Organizer to the learning results of the First Year Students of SMA Negeri 2 Padang" are accepted in the real level of 0,05 .
\end{abstract}

Keywords - Character Value, Advance Organizer, Physics Learning Outcomes

\section{PENDAHULUAN}

Pendidikan merupakan salah satu aspek kebutuhan manusia yang sangat penting dalam usaha untuk mengembangkan diri dalam kehidupan bermasyarakat dan bernegara. Tanpa pendidikan, suatu bangsa tidak akan bisa mengalami perubahan dan kemajuan. Oleh karena itu, pendidikan harus dipersiapkan sesuai dengan pekembangan zaman sebagai bekal kehidupan di masa yang akan datang.

Pemerintah sudah melakukan berbagai upaya untuk meningkatkan kualitas pendidikan di Indonesia. Hal tersebut terbukti dengan terjadinya perubahan kurikulum yang bertujuan untuk memperbaiki kurikulum sebelumnya, melengkapi semua fasilitas pembelajaran baik sarana maupun prasarana, bahkan telah memberikan berbagai pelatihan kepada guru yang mengajar agar terampil dan dapat menjalankan proses pembelajaran sebagaimana harapan dari pemerintah.

Salah satu upaya pemerintah untuk meningkatkan mutu pendidikan adalah dengan menerapkan pendidikan karakter. Pendidikan karakter merupakan salah satu tujuan pendidikan nasional, sebagaimana yang diamanatkan Pancasila, Pembukaan UUD 1945, dan UU No 20 tahun 2003.
Pendidikan karakter saat ini dilatar belakangi oleh belum tercapainya tujuan pendidikan nasional seutuhnya, dan banyaknya permasalahan yang terjadi di bangsa ini seperti kurangnya sikap toleransi terhadap sesama, maraknya tindakan asusila, dan munculnya berbagai macam tindakan anarkis. Salah satu upaya yang dilakukan oleh pemerintah untuk mengatasi hal tersebut adalah dengan menerapkan pendidikan karakter ke dalam sistem pendidikan nasional.

Satuan pendidikan merupakan suatu wadah untuk mengembangkan pendidikan karakter. Upaya pemerintah untuk mengembangkan pendidikan karakter di dalam satuan pendidikan adalah dengan mengintegrasikan pendidikan karakter ke dalam Kurikulum Tingkat Satuan Pendidikan (KTSP) yang ditegaskan di dalam Kurikulum 2013. Karakter merupakan sifat pribadi yang relatif stabil pada diri seseorang yang menjadi landasan bagi penampilan berperilaku dalam standar nilai dan norma yang tinggi ${ }^{[1]}$. Guna mencapai KTSP yang diharapkan, setiap satuan pendidikan harus mengembangkan kurikulum yang sesuai dengan karakteristik satuan pendidikannya. Salah satu hal yang dituntut dalam kurikulum adalah adanya suatu sumber belajar, dan 
salah satu sumber belajar menurut Depdiknas adalah bahan ajar.

Pendidikan karakter adalah upaya terencana untuk menjadikan peserta didik mengenal, peduli, dan menanamkan nilai-nilai sehingga peserta didik berprilaku sebagai insan kamil ${ }^{[2]}$. Pendidikan karakter yang diintegrasikan ke dalam kurikulum seperti harapan pemerintah masih ada yang belum berhasil. Hal ini disebabkan oleh kurangnya pengintegrasian nilai-nilai karakter ke dalam bahan ajar yang diberikan guru kepada siswa. Selain itu bahan ajar yang ada juga belum dilengkapi dengan keterkaitan antar konsep yang dipelajari dengan konsep yang sudah dipelajari sebelumnya.

Dalam mengembangkan karakter bangsa perlu diperhatikan pondasi-pondasinya. Pondasi-pondasi tersebut seperti di dalam Gambar 1 berikut ini:

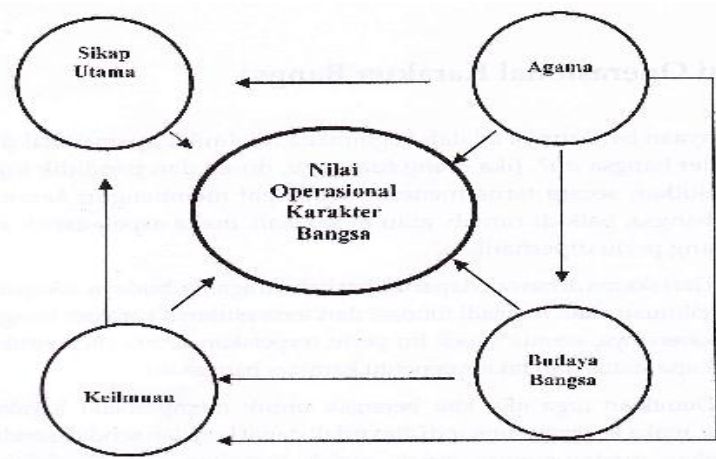

Gambar 1. Kerangka Nilai Operasional Karakter Bangsa

Berdasarkan Gambar 1 dapat dilihat bahwa agama, budaya, sikap utama, dan nilai keilmuan akan menjadi pondasi dari terbentuknya karakter bangsa $^{[3]}$. Dalam sebuah satuan pendidikan, aspek keilmuan adalah aspek utama untuk penanaman nilai-nilai karakter. Namun keempat unsur tersebut tidak dapat berjalan sendiri-sendiri karena satu sama lainnya berkaitan erat. Jika yang berjalan aspek keilmuan saja maka hal itu tidaklah cukup, karena agama, sikap utama, dan budaya berperan besar juga terhadap pengambangan karakter. Oleh karena itu karakter tidak perlu diajarkan khusus, namun dimasukkan secara inklusif dalam proses pendidikan.

Dalam kehidupan manusia sangat banyak nilai yang ada. Nilai yang ada dan melekat yang mencerminkan perilaku yang luar biasa tercermin pada diri Nabi Muhammad SAW, yaitu siddiq, amanah, fathanah, dan tabligh. Rasulullah SAW sudah terlebih dahulu memberikan contoh teladan yang baik dan akhlak mulia kepada kita sebagai umatnya. Jadi sebenarnya nilai-nilai karakter tersebut sudah berkembang dari zaman Rasulullah SAW, tapi belum kita kelompokkan seperti nilai-nilai karakter yang kita ketahui saat ini. Ada sebanyak 18 nilai yang perlu dikembangkan dalam pendidikan karakter $^{[4]}$. Nilai-nilai karakter tersebut seperti di dalam Tabel 1 berikut ini.
Tabel 1. Nilai dan Deskripsi Nilai Pendidikan Budaya dan Karakter Bangsa

\begin{tabular}{|c|c|}
\hline Nilai & Deskripsi \\
\hline 1 & 2 \\
\hline Religius & $\begin{array}{l}\text { Sikap dan tingkah laku yang patuh } \\
\text { dalam melaksanakan ajaran agama } \\
\text { yang dianut, toleran terhadap } \\
\text { pelaksanaan ibadah agama lain, dan } \\
\text { hidup berdampingan dengan pemeluk } \\
\text { agama lain. }\end{array}$ \\
\hline Jujur & $\begin{array}{l}\text { Perilaku yang dilandaskan pada } \\
\text { upaya menjadikan diri sebagai orang } \\
\text { yang selalu dapat dipercaya dalam } \\
\text { perkataan, tindakan, ataupun } \\
\text { pekerjaan. }\end{array}$ \\
\hline Toleransi & $\begin{array}{l}\text { Sikap dan perilaku yang menghargai } \\
\text { perbedaan agama, bahasa, suku, } \\
\text { etnis, pendapat, sikap, dan tingkah } \\
\text { laku orang lain yang berbeda dari } \\
\text { dirinya. }\end{array}$ \\
\hline Disiplin & $\begin{array}{l}\text { Tindakan yang menunjukkan tingkah } \\
\text { laku tertib dan patuh terhadap } \\
\text { berbagai ketentuan dan peraturan. }\end{array}$ \\
\hline $\begin{array}{l}\text { Kerja } \\
\text { Keras }\end{array}$ & $\begin{array}{l}\text { Tindakan yang menunjukkan } \\
\text { perilaku sungguh-sungguh dalam } \\
\text { mengatasi berbagai hambatan belajar } \\
\text { dan tugas, serta menyelesaikan tugas } \\
\text { dengan sebaik-baiknya. }\end{array}$ \\
\hline Kreatif & $\begin{array}{l}\text { Berpikir, mendapatkan ide bermanfat } \\
\text { dan melakukannya untuk meng- } \\
\text { hasilkan cara atau hasil baru dari } \\
\text { sesuatu yang telah dimiliki. }\end{array}$ \\
\hline Mandiri & $\begin{array}{l}\text { Sikap dan tingkah laku yang tidak } \\
\text { mudah tergantung terhadap orang } \\
\text { lain dalam menyelesaikan tugas- } \\
\text { tugas yang diberikan. }\end{array}$ \\
\hline $\begin{array}{l}\text { Demokra- } \\
\text { tis }\end{array}$ & $\begin{array}{l}\text { Cara berfikir, bersikap, berkata, dan } \\
\text { bertindak yang menilai sama antara } \\
\text { hak dan kewajiban diri dan orang } \\
\text { lain. }\end{array}$ \\
\hline $\begin{array}{l}\text { Rasa } \\
\text { Ingin } \\
\text { Tahu }\end{array}$ & $\begin{array}{l}\text { Sikap dan tindakan yang berupaya } \\
\text { untuk mengetahui dan memahami } \\
\text { lebih mendalam dan meluas dari } \\
\text { sesuatu yang sudah dipelajari, dilihat, } \\
\text { dan didengar. }\end{array}$ \\
\hline $\begin{array}{l}\text { Semanga } \\
\text { Kebangsa- } \\
\text { an }\end{array}$ & $\begin{array}{l}\text { Proses berfikir, bertindak, dan } \\
\text { berwawasan yang menempatkan } \\
\text { kepentingan bangsa dan negara di } \\
\text { atas kepentingan diri pribadi dan } \\
\text { kelompoknya. }\end{array}$ \\
\hline $\begin{array}{l}\text { Cinta } \\
\text { Tanah Air }\end{array}$ & $\begin{array}{l}\text { Cara berfikir, bersikap, dan berbuat } \\
\text { yang menunjukkan kesetiaan, } \\
\text { kepedulian, cinta, dan penghargaan } \\
\text { yang tinggi terhadap bahasa, } \\
\text { lingkungan fisik, teknoogi dan } \\
\text { informasi, sosial, budaya, ekonomi, } \\
\text { dan politik bangsa }\end{array}$ \\
\hline
\end{tabular}




\begin{tabular}{|c|c|}
\hline 1 & 2 \\
\hline $\begin{array}{l}\text { Menghar- } \\
\text { gai Presta- } \\
\text { si }\end{array}$ & $\begin{array}{lrr}\text { Sikap dan tindakan yang mampu } \\
\text { mendorong dirinya } & \text { untuk } \\
\text { mendapatkan sesuatu } & \text { yang } \\
\text { bermanfaat bagi masyarakat, dan } \\
\text { mengakui, menghargai, } & \text { serta } \\
\text { menghormati keberhasilan } & \text { orang } \\
\text { lain. } & & \end{array}$ \\
\hline $\begin{array}{l}\text { Bersaha- } \\
\text { bat/Komu } \\
\text { nikatif }\end{array}$ & $\begin{array}{l}\text { Tindakan yang menunjukkan rasa } \\
\text { senang berbicara, berinteraksi, dan } \\
\text { bekerja sama dengan orang lain }\end{array}$ \\
\hline $\begin{array}{l}\text { Cinta } \\
\text { Damai }\end{array}$ & $\begin{array}{l}\text { Sikap, perkataan, dan tindakan yang } \\
\text { menyebabkan orang lain merasa } \\
\text { bahagia dan merasa aman atas } \\
\text { kehadiran dirinya. }\end{array}$ \\
\hline $\begin{array}{l}\text { Gemar } \\
\text { Membaca }\end{array}$ & $\begin{array}{l}\text { Kebiasaan memanfaatkan waktu } \\
\text { untuk membaca berbagai bacaan } \\
\text { yang memberikan pengetahuan bagi } \\
\text { dirinya. }\end{array}$ \\
\hline $\begin{array}{l}\text { Peduli } \\
\text { Lingkung- } \\
\text { an }\end{array}$ & $\begin{array}{l}\text { Sikap dan tindakan yang selalu } \\
\text { berusaha untuk mencegah kerusakan } \\
\text { pada lingkungan di sekitar, dan } \\
\text { mengem-bangkan upaya-upaya untuk } \\
\text { memperbaiki kerusakan alam yang } \\
\text { sudah terjadi. }\end{array}$ \\
\hline $\begin{array}{l}\text { Peduli } \\
\text { Sosial }\end{array}$ & $\begin{array}{l}\text { Sikap dan tindakan yang selalu ingin } \\
\text { memberi pertolongan pada orang lain } \\
\text { dan masyarakat saat membutuhkan. }\end{array}$ \\
\hline $\begin{array}{l}\text { Tanggung } \\
\text { Jawab }\end{array}$ & $\begin{array}{l}\text { Sikap dan tingkah laku untuk } \\
\text { melakukan tugas dan kewajibannya, } \\
\text { yang seharusnya dia lakukan, } \\
\text { terhadap diri sendiri, masyarakat, } \\
\text { lingkungan (alam, sosial dan } \\
\text { budaya), negara dan Tuhan Yang } \\
\text { Maha Esa. }\end{array}$ \\
\hline
\end{tabular}

Berdasarkan kurikulum 2013, nilai-nilai karakter dibuat khusus pada Kompetensi Inti 1(KI 1) dan Kompetensi Inti 2 (KI 2). Nilai karakter ini dituntut untuk dikembangkan khusus dalam proses pembelajaran karena terintegrasi pada Kompetensi Inti 3 (KI 3) dan Kompetensi Inti 4 (KI 4). Kompetensi inti mencakup sikap spiritual, sikap sosial, pengetahuan dan keterampilan. Untuk menerapkan KI 1 dan KI 2 diperlukan bahan ajar yang mendukung kegiatan pembelajaran. Bahan ajar adalah segala bentuk bahan yang digunakan untuk membantu guru dalam melaksanakan kegiatan pembelajaran $^{[5]}$. Bahan ajar yang dikembangkan adalah dalam bentuk model pembelajaran advance organizer yang terintegrasi nilai karakter.

Model pembelajaran advance organizer adalah salah satu model pembelajaran yang dapat meningkatkan aktivitas siswa serta dapat mengaitkan materi lama dengan materi selanjutnya. Model pembelajaran advance organizer ini diintegrasikan ke dalam bentuk bahan ajar. Model pembelajaran advance organizer memiliki tujuan untuk melihat kebermaknaan konsep yang akan dipelajari dan menghubungkannya dengan konsep yang sudah dimiliki serta membuat siswa lebih aktif dalam proses pembelajaran. Materi yang sudah dipelajari siswa dapat dimanfaatkan menjadi titik tolak dalam mengkomunikasikan informasi atau ide baru dalam kegiatan pembelajaran, sehingga siswa dapat melihat hubungan antara materi pelajaran yang telah dipelajari dengan informasi atau ide baru yang akan dipelajari.

Melalui bahan ajar dengan model pembelajaran advance organizer ini diintegrasikan nilai karakter religius, jujur, disiplin, kerja keras, dan rasa ingin tahu. Penerapan nilai-nilai karakter ke dalam bahan ajar dengan model pembelajaran advance organizer, siswa dapat lebih mudah memahami keterkaitan antar konsep dalam materi pembelajaran fisika, dan dapat menerapkan nilai karakter yang dilengkapi juga dengan ayat Al Qur'an yang relevan dengan materi yang sedang dipelajari.

Keunggulan model pembelajaran advance organizer adalah siswa dapat mengaitkan materi lama dengan materi selanjutnya dengan menggunakan sebuah organizer (kerangka umum) berupa peta konsep, mind map, dan diagram KWHL ( Know, What, How, Learn ). Tahap - tahap dalam model pembelajaran Advance Organizer yaitu tahap penyajian Advance Organizer, tahap penyajian materi pembelajaran dan tahap memperkuat struktur kognitif siswa ${ }^{[6]}$. Tahap-tahap tersebut membuat model pembelajaran Advance Organizer unggul dari model pembelajaran lain karena membuat siswa lebih aktif dalam proses pembelajaran. Peta konsep merupakan salah satu bagian dari strategi pembelajaran yang bertujuan untuk membantu siswa dalam meningkatkan aktivitas siswa dalam proses pembelajaran. Peta konsep dimanfaatkan untuk melihat hubungan yang bermakna antar konsepkonsep. Contoh dari peta konsep dapat dilihat pada Gambar 2.

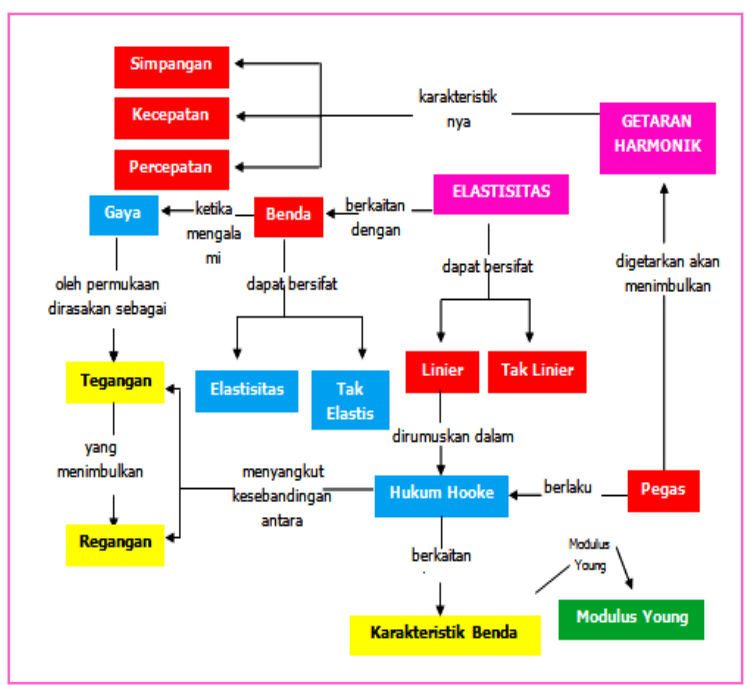

Gambar 2. Peta Konsep dengan Materi Elastisitas

Berdasarkan Gambar 2 dapat dilihat bahwa materi 
elastisitas dijabarkan melalui peta konsep. Siswa dapat menambahkan nilai karakter yang terkandung dalam materi pembelajaran. Peta konsep diberikan di awal pembelajaran sehingga dapat memudahkan siswa dalam mengingat materi pembelajaran.

Mind Map merupakan suatu organizer dalam model pembelajaran advance organizer. Mind Map atau peta pikiran adalah suatu teknik mencatat yang mampu mengembangkan pikiran dan meningkatkan daya ingat karena informasi disusun secara bercabang dari tema utama yang menyertakan gambar, symbol, warna, dan teks ${ }^{[7]}$. Mind Map menggabungkan dan mengembangkan potensi kerja otak yang terdapat dalam diri seseorang. Adanya keterlibatan kedua belah otak akan memudahkan seseorang untuk mengatur dan mengingat segala bentuk informasi, baik secara tulisan maupun secara lisan. Adanya perpaduan warna, simbol, gambar, dan sebagainya memudahkan otak dalam menyerap informasi yang diterima.

Salah satu bentuk dari Mind Map dapat dilihat pada Gambar 3.

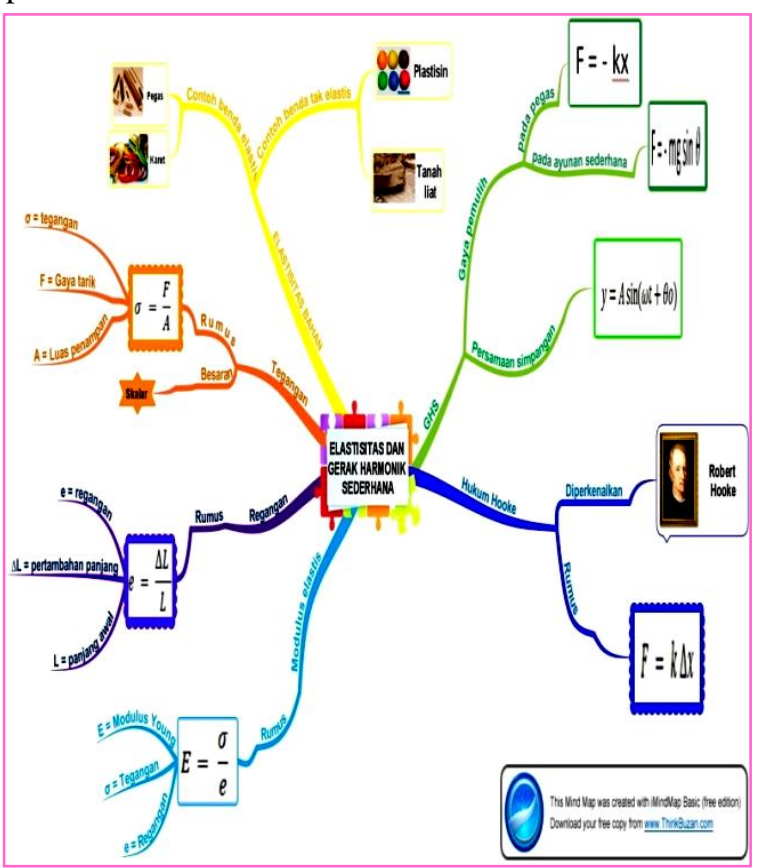

Gambar 3. Mind Map dengan Materi Elastisitas

Berdasarkan Gambar 3 dapat dilihat bahwa mind map berisi peta pikiran yang dibuat oleh siswa setelah mendapatkan materi pembelajaran.

Bentuk organizer terakhir adalah Teknik KWHL (Know-Want-How-Learned) merupakan strategi pembelajaran yang membantu siswa mengembangkan cara praktis untuk belajar materi baru dengan menggunakan pertanyaan dan mengakses informasi dari sumber terpercaya. KWHL merupakan salah satu organizer dalam model pembelajaran advance organizer. Strategi ini bisa efektif dalam mempromosikan kemandirian dalam belajar. Usia dan tahapan pembangunan akan menentukan peran guru dalam membimbing siswa memainkan melalui proses KWHL.

KWHL merupakan singkatan dari komponen: $\mathbf{K}$ (Know) apa yang sudah anda ketahui tentang subjek, W (Want) apa yang anda inginkan untuk belajar, H (How) adalah untuk mencari tahu bagaimana anda dapat mempelajari lebih lanjut tentang topik, $\mathbf{L}$ (Learned) adalah untuk apa anda belajar saat membaca. Bentuk dari diagram KWHL dapat dilihat pada Tabel 2.

Tabel 2. Diagram KWHL dengan Topik Elastisitas

\begin{tabular}{|c|c|c|c|c|}
\hline $\begin{array}{l}\mathrm{N} \\
\mathrm{O}\end{array}$ & $\begin{array}{c}\mathrm{K} \\
(K N O W)\end{array}$ & $\begin{array}{c}\mathrm{W} \\
(W A N T)\end{array}$ & $\begin{array}{c}\mathrm{H} \\
(\mathrm{HOW})\end{array}$ & $\begin{array}{c}\mathrm{L} \\
(L E A R N E D)\end{array}$ \\
\hline 1 & $\begin{array}{l}\text { - Gaya } \\
\text { dapat } \\
\text { merubah } \\
\text { bentuk } \\
\text { benda. } \\
\text { - Energi } \\
\text { potensial } \\
\text { contoh } \\
\text { benda: } \\
\text { ketapel, } \\
\text { karet, } \\
\text { dll. }\end{array}$ & $\begin{array}{c}\text { Elastisitas } \\
\text { - Benda } \\
\text { elastis } \\
\text { - Benda } \\
\text { plastis. }\end{array}$ & $\begin{array}{l}\text { - Menaruh } \\
\text { batu kecil } \\
\text { pada karet } \\
\text { ketapel dan } \\
\text { menarik } \\
\text { karet } \\
\text { tersebut } \\
\text { sehingga } \\
\text { bentuk karet } \\
\text { berubah, } \\
\text { lalu } \\
\text { melepaskan } \\
\text { tarikannya. } \\
\text { - Membedaka } \\
\text { n benda } \\
\text { elastis } \\
\text { dengan } \\
\text { benda } \\
\text { plastis. }\end{array}$ & 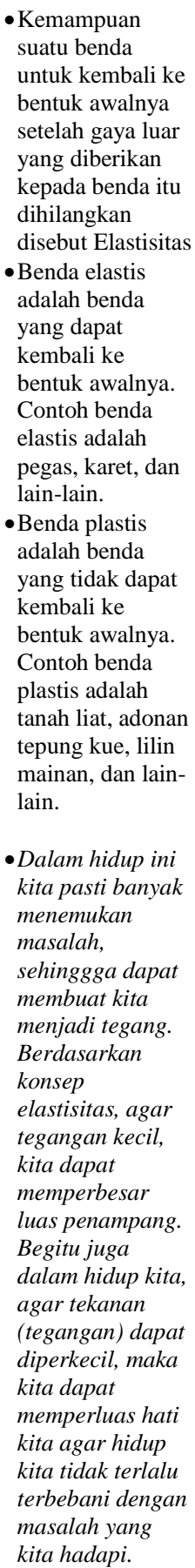 \\
\hline
\end{tabular}


Berdasarkan Tabel 2 dapat dilihat pada kolom Learned diintegrasikan nilai karakter yang berkaitan dengan materi pembelajaran. Siswa juga ditugaskan untuk mencari nilai-nilai karakter yang berhubungan dengan materi. Pengintegrasian nilai-nilai karakter ke dalam bahan ajar dapat meningkatkan motivasi belajar siswa karena siswa dapat mengetahui nilainilai karakter yang terdapat di dalam materi pembelajaran.

Diharapkan dari keunggulan model pembelajaran Advance Organizer ini dapat memperkuat struktur kognitif siswa yang nantinya akan tercipta suatu model kerangka pikir tentang suatu konsep baru dari sebuah materi pelajaran yang berguna untuk memulai suatu pelajaran baru sehingga pelajaran tersebut menjadi lebih efektif dan bermakna. Bahan ajar yang terintegrasi nilai karakter dalam suatu model pembelajaran yang diterapkan dapat meningkatkan hasil belajar yang optimal.

Tujuan yang ingin dicapai dalam penelitian ini adalah untuk melihat perbedaan hasil belajar Fisika siswa antara penerapan bahan ajar terintegrasi nilai karakter dalam model pembelajaran Advance Organizer dengan siswa yang menggunakan bahan ajar tidak terintegrasi nilai karakter dalam model pembelajaran Advance Organizer di SMA Negeri 2 Padang.

\section{METODE PENELITIAN}

Jenis penelitian yang dilakukan adalah Quasi Experiment Research (penelitian eksperimen semu). Tujuan dari penelitian eksperimen semu adalah untuk memperoleh informasi yang merupakan perkiraan informasi dalam keadaan yang tidak memungkinkan untuk mengendalikan atau mengubah semua variabel yang relevan. Penelitian ini dirancang dengan menggunakan rancangan Randomized Control Group Only Design, [8]. Rancangan penelitian ini dapat dilihat pada Tabel 3.

Tabel 3. Rancangan Penelitian

\begin{tabular}{|c|c|c|c|}
\hline Group & Pretest & Treatment & Posttest \\
\hline Eksperimen & - & $\mathrm{X}$ & $\mathrm{T}$ \\
\hline Kontrol & - & - & $\mathrm{T}$ \\
\hline
\end{tabular}

Perlakuan yang diberikan pada kelas eksperimen yaitu penggunaan bahan ajar terintegrasi nilai karakter dalam model pembelajaran Advance Organizer, sedangkan pada kelas kontrol hanya menggunakan bahan ajar dalam model pembelajaran Advance Organizer saja. Jadi, variabel bebasnya adalah bahan ajar terintegrasi nilai karakter dalam model pembelajaran Advance Organizer, variabel terikatnya adalah hasil belajar fisika pada ranah kognitif, afektif, dan psikomotor, dan variabel kontrolnya adalah guru, sumber belajar, dan waktu yang digunakan adalah sama, jumlah dan jenis soal yang diberikan pada kedua kelas sama.

Populasi dari penelitian ini adalah semua siswa kelas X SMA Negeri 2 Padang yang terdaftar pada Semester 2 Tahun Ajaran 2013/ 2014. Pengambilan sampel dilakukan dengan teknik Cluster Random. Pengambilan sampel secara cluster (rumpun) merupakan pengambilan sampel pada kelompok individu-individu yang telah ada di sekolah yaitu kelas, bukan secara individu. Didapat kelas X-IPA.1 dijadikan sebagai kelas eksperimen dan X-IPA.4 dijadikan sebagai kelas kontrol.

Data pada penelitian ini adalah perolehan hasil belajar siswa pada mata pelajaran Fisika setelah diberi perlakuan yang meliputi hasil belajar ranah kognitif yang diambil melalui tes akhir dalam bentuk Multiple Choice Test, hasil belajar ranah afektif yang didapatkan melalui format penilaian afektif, dan hasil belajar ranah psikomotor melalui rubrik penskoran. Prosedur penelitian dilakukan melalui beberapa tahap, yaitu tahap persiapan, tahap pelaksanaan, dan tahap penyelesaian.

Instrumen hasil belajar ranah kognitif yang digunakan adalah tes objektif dengan lima pilihan jawaban (Multiple Choice Test) yang dilaksanakan di akhir penelitian. Langkah pertama adalah melakukan uji coba soal tes akhir berdasarkan kisi-kisi soal uji coba yang telah dibuat sebelumnya yaitu, sebanyak 40 butir soal. Berdasarkan hasil uji coba dilakukan analisis soal agar kita bisa mengetahui validitas soal, reliabilitas soal, tingkat kesukaran soal, dan daya beda soal. Hasil dari analisis soal uji coba diperoleh soal tes akhir sebanyak 30 butir.

Validitas yang digunakan dalam penelitian ini adalah validitas isi (content validity). Validitas isi adalah validitas yang ditelusuri lebih lanjut dari sudut pandang tes itu sebagai alat pengukur hasil belajar siswa, yang isinya telah dapat mewakili terhadap keseluruhan materi atau topik kajian yang seharusnya diujikan. Instrumen dikatakan valid apabila dapat mengukur apa yang diinginkan atau dapat mengungkap data dari variabel yang diteliti secara tepat. Reliabilitas merupakan ketepatan suatu tes yang digunakan pada subjek yang sama pada waktu yang berbeda. Reliabilitas soal dapat diukur menggunakan rumus Kuder Richaderson (KR-21) ${ }^{[9]}$. Berdasarkan tes uji coba yang telah dilakukan, didapatkan nilai reliabilitas soal sebesar 0,70 dengan kriteria tinggi. 
Analisis tingkat kesukaran dilakukan untuk melihat apakah soal yang telah dibuat terlalu mudah atau terlalu sulit. Bilangan tersebut disebut indeks kesukaran $^{[10]}$. Berdasarkan hasil analisis didapatkan 10 soal dengan kriteria mudah, 19 soal kriteria sedang, dan 11 soal kriteria sukar. Soal yang digunakan dalam penelitian ini adalah soal yang mempunyai tingkat kesukaran antara 0,30 s/d 0,70.

Sedangkan kemampuan soal untuk membedakan siswa yang memiliki kemampuan rendah dengan siswa yang memiliki kemampuan tingggi disebut daya pembeda soal ${ }^{[11]}$. Berdasarkan hasil analisis soal uji coba pada kelas X IPA.3 di SMA Negeri 2 Padang, soal yang diterima memiliki indeks daya beda >0,3. Setelah dianalisis dari 40 buah soal yang diujicobakan didapatkan kriteria 17 butir soal diterima, 13 butir soal direvisi, dan 10 butir soal ditolak.

Instrumen hasil belajar ranah afektif adalah format penilaian ranah afektif yang dibuat peneliti berdasarkan indikator-indikator penilaian sikap atau prilaku siswa selama proses pembelajaran berlangsung yang dibantu oleh bantuan dua orang observer. Sedangkan instrumen hasil belajar ranah psikomotor menggunakan rubrik penskoran yang diperoleh pada saat siswa melakukan praktikum di laboratorium. Pada penelitian ini percobaan dilakukan dua kali, pertama pada materi Elastisitas, dan kedua pada materi fluida statik.

Teknik analisis data untuk ranah penilaian kognitif dan psikomotor menggunakan uji kesamaan dua rata-rata. Sebagaimana dilakukan uji normalitas dengan menggunakan uji Lilliefors ${ }^{[12]}$. Uji Homogenitas dengan menggunakan Uji - $\mathrm{F}^{[12]}$. Uji normalitas bertujuan untuk mengetahui apakah data terdistribusi normal atau tidak, sedangkan uji homogenitas bertujuan untuk mengetahui apakah data yang kita memiliki varians yang homogen atau tidak. Ranah afektif menggunakan teknik analisis data yang dibuat ke dalam bentuk grafik.

Setelah kita lakukan uji normalitas dan uji homogenitas, maka dilakukan uji hipotesis. Pada penelitian yang telah dilakukan, menggunakan uji- $t$ untuk hasil belajar ranah kognitif dan psikomotor ${ }^{[12]}$, sedangkan pada hasil belajar ranah afektif menggunakan grafik.

\section{HASIL DAN PEMBAHASAN}

Data hasil belajar ranah kognitif diperoleh melalui tes tertulis setelah proses pembelajaran di akhir kegiatan penelitian, data hasil belajar ranah afektif diperoleh selama proses pembelajaran melalui lembar observasi, dan data hasil belajar ranah psikomotor diperoleh selama kegiatan praktikum melalui rubrik penskoran. Data hasil belajar ranah kognitif siswa bisa dilihat pada Tabel 4.
Tabel 4. Data Hasil Belajar Ranah Kognitif Kelas Sampel

\begin{tabular}{|c|c|c|c|c|c|}
\hline Kelas & $\mathrm{N}$ & $\begin{array}{c}\text { Nilai } \\
\text { Tertinggi }\end{array}$ & $\begin{array}{c}\text { Nilai } \\
\text { Terendah }\end{array}$ & $\bar{X}$ & $S^{2}$ \\
\hline \hline $\begin{array}{c}\text { Eksperi } \\
\text { men }\end{array}$ & 32 & 97,00 & 47,00 & 80,00 & 214,12 \\
\hline \hline Kontrol & 32 & 93,00 & 45,00 & 72,50 & 165,99 \\
\hline
\end{tabular}

Tabel 4 menampilkan nilai rata-rata hasil belajar siswa di kelas kontrol lebih rendah bila dibandingkan hasil belajar siswa di kelas eksperimen pada ranah kognitif. Nilai varians kelas eksperimen lebih besar dibandingkan nilai varians kelas kontrol, artinya hasil belajar kelas eksperimen lebih beragam dibandingkan hasil belajar kelas kontrol.

Analisis data hasil belajar ranah kognitif, dilakukan dengan menggunakan uji normalitas, yang bertujuan untuk mengetahui apakah data terdistribusi secara normal atau tidak. Setelah uji normalitas, kemudian dilakukan uji homogenitas. Tujuan dari uji homogenitas adalah untuk mengetahui apakah data memiliki varians yang homogen atau tidak. Dari hasil tersebut, nantinya kita bisa melihat variasi nilai kedua kelas sampel.

Berdasarkan uji normalitas dan homogenitas pada kedua kelas sampel, maka diperoleh data tes akhir kelas sampel pada hasil belajar ranah kognitif . Selanjutnya dilakukan uji kesamaan dua rata-rata menggunakan uji hipotesis yaitu uji $t$, karena data terdistribusi normal dan memilki varians yang homogen. Hasil uji $t$ hasil belajar ranah kognitif dapat dilihat pada Tabel 5 .

Tabel 5. Hasil Uji $t$ Ranah Kognitif

\begin{tabular}{|c|c|c|c|c|c|}
\hline Kelas & $\mathrm{N}$ & Mean & $S^{2}$ & $t_{h}$ & $t_{t}$ \\
\hline Eksperimen & 32 & 80,00 & 214,12 & \multirow{2}{*}{2,17} & \multirow{2}{*}{1,67} \\
\hline Kontrol & 32 & 72,50 & 165,99 & & \\
\hline
\end{tabular}

Tabel 5 memperlihatkan bahwa $t_{\text {hitung }}=2,17$ sedangkan $t_{\text {tabel }}=1,67$. Kriteria penerimaan $\mathrm{H}_{0}$ jika - $\mathrm{t}(1-\alpha)<\mathrm{t}<\mathrm{t}(1-\alpha)$ atau $-1,67<\mathrm{t}<1,67$. Nilai $t_{\text {hitung }}=2,17$ berada di luar daerah penerimaan $\mathrm{H}_{0}$. Jadi dapat disimpulkan hipotesis kerja Hi diterima. Data ini memperlihatkan keberartian perbedaan, bahwa terdapat perbedaan hasil belajar ranah kognitif antara kelas eksperimen dengan kelas kontrol setelah diberikan perlakuan yang berbeda.

Penilaian hasil belajar ranah afektif dilakukan terhadap enam nilai karakter penilaian dengan beberapa indikator yang disesuaikan dengan materi dan kemampuan belajar siswa. Nilai - nilai karakter yang diintegrasikan ke dalam bahan ajar adalah religius, kerja keras, tangggung jawab, disiplin, rasa ingin tahu, dan jujur. Data hasil belajar ranah afektif dapat dilihat pada Tabel 6. 
Tabel 6. Data Hasil Belajar Ranah Afektif Kelas Sampel

\begin{tabular}{|l|c|c|c|c|c|c|c|}
\hline \multirow{2}{*}{ Kelas } & $\mathrm{N}$ & $\begin{array}{c}\text { Reli } \\
\text { gius }\end{array}$ & $\begin{array}{c}\text { Kerja } \\
\text { Keras }\end{array}$ & $\begin{array}{c}\text { Tang } \\
\text { gung } \\
\text { jawab }\end{array}$ & $\begin{array}{c}\text { Disip } \\
\text { lin }\end{array}$ & $\begin{array}{c}\text { Ingin } \\
\text { tahu }\end{array}$ & Jujur \\
\hline $\begin{array}{l}\text { Ekspe } \\
\text { rimen }\end{array}$ & 32 & 82 & 78 & 80 & 80 & 80 & 80 \\
\hline $\begin{array}{l}\text { kon } \\
\text { trol }\end{array}$ & 32 & 76 & 72 & 76 & 74 & 72 & 74 \\
\hline
\end{tabular}

Tabel 6 menampilkan nilai hasil belajar siswa di kelas eksperimen lebih tinggi dibanding kelas kontrol pada ranah afektif.

Analisis data penilaian afektif dapat dikonversi ke dalam bentuk Gambar 4.

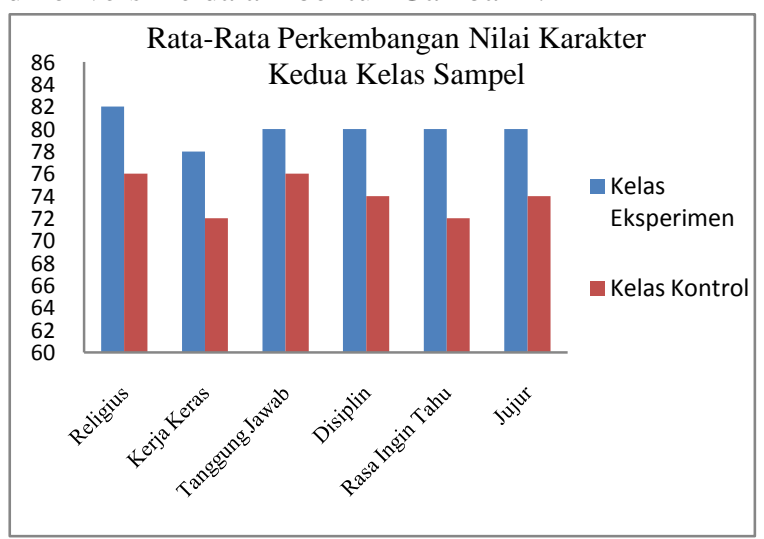

Gambar 4. Grafik Penilaian Ranah Afektif

Berdasarkan Gambar 4 terlihat bahwa pada kelas eksperimen nilai karakter yang menonjol adalah karakter religius dengan nilai 82. Kelas kontrol nilai karakter yang menonjol adalah tanggung jawab dengan nilai 76.

Penilaian hasil belajar ranah psikomotor diperoleh melalui hasil pengamatan selama kegiatan praktikum berlangsung. Data hasil belajar ranah psikomotor dapat dilihat pada Tabel 7.

Tabel 7. Data Hasil Belajar Ranah Psikomotor Kelas Sampel

\begin{tabular}{|c|c|c|c|c|c|}
\hline Kelas & $\mathrm{N}$ & $\begin{array}{c}\text { Nilai } \\
\text { Tertinggi }\end{array}$ & $\begin{array}{c}\text { Nilai } \\
\text { Terendah }\end{array}$ & $\bar{X}$ & $S^{2}$ \\
\hline $\begin{array}{c}\text { Eksperi } \\
\text { men }\end{array}$ & 32 & 98 & 80 & 89,00 & 28,38 \\
\hline Kontrol & 32 & 94 & 70 & 79,75 & 37,99 \\
\hline
\end{tabular}

Tabel 7 memperlihatkan bahwa rata-rata nilai hasil belajar siswa pada kelas kontrol lebih rendah dibandingkan kelas eksperimen pada ranah psikomotor. Nilai varians kelas eksperimen lebih kecil dibandingkan nilai varians kelas kontrol, artinya hasil belajar kelas kontrol lebih beragam dibandingkan hasil belajar kelas eksperimen.

Analisis data hasil belajar ranah psikomotor sama dengan kognitif, yaitu dilakukan dengan menggunakan uji normalitas, yang bertujuan untuk mengetahui apakah data terdistribusi secara normal atau tidak. Setelah uji normalitas, kemudian dilakukan uji homogenitas. Tujuan dari uji homogenitas adalah untuk mengetahui apakah data memiliki varians yang homogen atau tidak.

Berdasarkan uji normalitas dan homogenitas pada kedua kelas sampel, maka diperoleh data tes akhir kelas sampel pada hasil belajar ranah psikomotor. Selanjutnya dilakukan uji kesamaan dua rata-rata menggunakan uji hipotesis yaitu uji $t$, karena data terdistribusi normal dan memilki varians yang homogen. Hasil uji $t$ hasil belajar ranah kognitif dapat dilihat pada Tabel 8.

Tabel 8. Hasil Uji $t$ Ranah Psikomotor

\begin{tabular}{|c|c|c|c|c|c|}
\hline Kelas & $\mathrm{N}$ & Mean & $S^{2}$ & $t_{h}$ & $t_{t}$ \\
\hline Eksperimen & 32 & 89,00 & 28,38 & \multirow{2}{*}{6,42} & \multirow{2}{*}{1,67} \\
\hline Kontrol & 32 & 79,75 & 37,99 & & \\
\hline
\end{tabular}

Tabel 8 memperlihatkan bahwa $t_{\text {hitung }}=6,42$ sedangkan $t_{\text {tabel }}=1,67$, Kriteria penerimaan $\mathrm{H}_{0}$ jika - $\mathrm{t}(1-\alpha)<\mathrm{t}<\mathrm{t}(1-\alpha)$ atau $-1,67<\mathrm{t}<1,67$. Nilai $t_{\text {hitung }}=6,42$ berada di luar daerah penerimaan $\mathrm{H}_{0}$ pada taraf nyata 0,05 dan derajat kebebasannya adalah $d k=\left(\mathrm{n}_{1}+\mathrm{n}_{2}\right)-2$. Data ini memperlihatkan keberartian perbedaan, bahwa terdapat perbedaan yang signifikan antara kelas eksperimen dengan kelas kontrol setelah diberikan perlakuan yang berbeda.

Berdasarkan penelitian yang telah dilaksanakan terjadi peningkatan hasil belajar Fisika siswa untuk ranah kognitif, afektif, dan psikomotor. Salah satu penyebab terjadinya peningkatan ini yaitu penggunaan bahan ajar berbasis Advance Organizer yang terintegrasi nilai karakter. Bahan ajar ini dapat membangkitkan minat siswa dalam pembelajaran Fisika karena bahan ajar memiliki tampilan yang menarik dan dilengkapi dengan nilai-nilai karakter dalam setiap materi.

Hasil analisis data tes akhir belajar didapat dari nilai rata-rata belajar siswa dari ketiga ranah yaitu ranah kognitif, afektif dan psikomotor menunjukkan bahwa penerapan bahan ajar terintegrasi nilai karakter dalam model pembelajaran advance organizer dapat meningkatkan pencapaian kompetensi belajar Fisika siswa. Hal ini terlihat dari nilai rata-rata tes akhir, sikap dan keterampilan, siswa yang menerapkan bahan ajar yang terintegrasi nilai karakter dari pada rata-rata nilai siswa yang memakai bahan ajar dalam model pembelajaran advance organizer yang tidak terintegrasi nilai karakter.

Model pembelajaran advance organizer dapat menumbuhkan kreatifitas siswa dalam belajar. Hal ini terbukti dengan antusisnya siswa saat membuat peta konsep dan mind map. Siswa diberi kebebasan untuk menggambar sesuai dengan idenya masingmasing, sehingga hasilnya sangat bervariasi dan 
menarik. Pada kelas eksperimen, siswa menambahkan nilai-nilai karakter yang relevan dengan konsep yang sedang dipelajari.

Fase pertama, guru menyajikan secara singkat Organizer seperti peta konsep yang ada di bahan ajar kepada siswa. Pada fase kedua, guru menyajikan materi pembelajaran yang ditambah dengan nilainilai krakter yang relevan secara singkat kepada siswa, kemudian dilanjutkan dengan diskusi kelompok untuk menjawab soal-soal pada bahan ajar. Penggunaan bahan ajar berbasis Advance Organizer terintegrasi nilai karakter menuntun siswa untuk bekerja keras memahami materi pembelajaran. Materi yang belum dipahami dapat ditanyakan siswa kepada teman dalam satu kelompok dan teman beda kelompok saat diskusi berlangsung. Pada fase ketiga, struktur kognitif siswa diperkuat dengan penggunaan diagram KWHL. Diagram KWHL memiliki pertanyaan yang harus dijawab siswa pada bagian L (Learned) yang juga ditambahkan dengan nilai karakter, sehingga siswa dapat menemukan nilai karakter yang relevan dengan materi pembelajaran. Selain itu, siswa juga diajak untuk berpikir secara sistematis sesuai dengan kerja otak untuk mampu menghasilkan karya bagus dan menarik berupa mind map yang dilengkapi dengan nilai karakter sebagai pekerjaan rumah.

\section{KESIMPULAN}

Setelah melakukan penelitian terhadap pengaruh penerapan bahan ajar terintegrasi nilai karakter dalam model pembelajaran Advance Organizer pada siswa kelas X SMA Negeri 2 Padang dan melakukan pengolahan data, dapat diambil kesimpulan bahwa:

1. Terdapat perbedaan hasil belajar Fisika siswa dengan penerapan bahan ajar terintegrasi nilai karakter dalam model pembelajaran Advance Organizer dengan penerapan bahan ajar tidak terintegrasi nilai karakter dalam model pembelajaran Advance Organizer.

2. Model pembelajaran Advance Organizer juga memberikan pengaruh terhadap hasil belajar Fisika siswa di kelas X SMA N 2 Padang pada ranah afektif dan psikomotor yang ditandai dengan peningkatan keaktifan, keterampilan siswa, dan sikap positif siswa dalam belajar. Nilai rata-rata hasil belajar pada ranah afektif 74,00 pada kelas kontrol dan 80,00 pada kelas eksperimen. Nilai rata-rata hasil belajar pada ranah psikomotor 79,75 pada kelas kontrol dan 89,00 pada kelas eksperimen.

\section{DAFTAR PUSTAKA}

[1] Prayitno dan Belferik Manullang. 2011. Pendidikan Karakter dalam Pembangunan Bangsa. Jakarta: Grasindo.

[2] Policy Brief, 2011. Pendidikan Karakter Untuk Membangun Karakter Bangsa. Jakarta: Kemendiknas

[3] Kementrian Pendidikan Nasional. 2011. Pedoman Pelaksanaan Pendidikan Karakter. Jakarta: Balitbang Pusat Kurikulum dan Perbukuan

[4] Puskur.2010. Pengembangan Pendidikan Budaya dan Karakter Bangsa. Jakarta: Kemendiknas

[5] Depdiknas. 2008. Kumpulan Permen. Jakarta Dirjen Dikti

[6] Joyce, B., Weil, M., dan Calhoun, E. 2011. Models of Teaching: Model-model Pengajaran (Terjemahan Fawaid, A., dan Mierza, A.,). New Jersey: Pearson Education. Buku asli diterbitkan tahun 1972.

[7] Buzan, Tony. 2007. Mind Mapping. Jakarta : Gramedia.

[8] Sumadi Suryabrata. 2006. Metodologi Penelitian. Jakarta: Gravindo Persada.

[9] Suharsimi Arikunto. 2012. Dasar-Dasar Evaluasi Pendidikan. Jakarta: Rineka Cipta

[10] Sumarna Surapranata. 2005. Analisis, Validitas, Reabilitas, dan Interpretasi Hasil Tes. Bandung: PT. Remaja Rosdakarya

[11] Suharsimi Arikunto. 2008. Dasar-Dasar Evaluasi Pendidikan. Jakarta: Bumi Aksara

[12] Sudjana. 2002. Metoda Statistika. Bandung: Tarsito 